\title{
Gastrointestinal stromal tumors and second primary malignancies: a retrospective monocentric analysis
}

\author{
D. COMANDINI ${ }^{1}$, M. GRASSI ${ }^{1}$, A. PRELAJ ${ }^{2}$, V. MARTELLI ${ }^{1}$, A. DAMIANI ${ }^{1}$, G. DAMIANO ${ }^{1}$, S. E. REBUZZI ${ }^{1, \star}$ \\ ${ }^{1}$ Medical Oncology Unit 1, IRCCS Ospedale Policlinico San Martino, University of Genova, Genova, Italy; ${ }^{2}$ Medical Oncology Department 1, \\ Fondazione IRCCS Istituto Nazionale Tumori, University of Milan, Milan, Italy
}

*Correspondence: saraelena89@hotmail.it

Received March 1, 2020 / Accepted April 8, 2020

\begin{abstract}
In the post-Imatinib era, the median survival of patients diagnosed with GIST has reached almost 5 years. Prolonging GIST-specific survival, GIST patients have an increased incidence of secondary neoplasia. Data on the prognostic impact of second tumors in GIST patients are very poor with few and small retrospective analyses available in the literature. We conducted a retrospective monocentric analysis on 145 patients diagnosed with GIST between April 2001 and October 2018. Kaplan-Meier and Cox hazard methods were used for survival analysis. A total of 154 GIST patients were included and 31 patients of them (21\%) were diagnosed with at least one additional malignancy. The most common second tumors associated with GIST were gastrointestinal tumors. GIST patients with additional malignancies showed to have lower size (>5 cm: $35 \%$ vs $45 \%$; $\mathrm{p}=0.75$ ), higher mitotic rate (>5/50 HPFs: $42 \%$ vs $29 \%$; $\mathrm{p}=0.24$ ), higher presence of c-KIT mutation ( $85 \%$ vs 69\%), a lower presence of PDGFRa mutation ( $8 \%$ vs $17 \%$; $\mathrm{p}=0.05$ ) and shorter survival (mOS: 9.6 vs 15.5 years; $\mathrm{p}=0.30$ ). In conclusion, our study did not find any significant correlation between clinicopathological characteristics and the development of a second tumor in GIST patients. Further analyses and strict follow up protocols are needed in order to early diagnose and promptly treat a second primary tumor in the GIST population.
\end{abstract}

Key words: gastrointestinal stromal tumors, second primary cancer, second malignancies, second cancer risk, synchronous, metachronous

Gastrointestinal stromal tumors (GISTs) are the most common mesenchymal neoplasms in the gastrointestinal (GI) tract, affecting 10-15 people per million per year in Western countries [1]. The incidence is estimated to be higher in the Asian population at 16-20 per million per year [2], whereas it is estimated to be 6.8 per million per year in the USA [3]. There are no studies available with data on global incidence and prevalence. The most common sites of GISTs are stomach (50-60\%) and small intestine (30-35\%), and less frequently colon, rectum, appendix, and esophagus [4].

The activating mutation of c-KIT and PDGFRa genes are the most common driver mutation of GIST occurring in approximately $90 \%$ of cases [5]. Up to $10 \%$ of cases are related to mutations of the SDH complex, BRAF, or NF1 genes. The identification of mutation of the c-KIT gene is fundamental for the diagnosis, the molecular classification, the therapeutic management, and consequently the outcomes of GIST patients [6]. Most GISTs are sporadic ( $95 \%)$ but in some cases, they are observed in the context of hereditary syndromes due to germline mutations in c-KIT, PDGFRa,
NF1, and SDH genes, such as Carney's triad, Carney-Stratakis syndrome, and neurofibromatosis type 1, in which GISTs are associated with multiple additional benign and malignant tumors $[7,8]$. In several single-institution case series and reviews, patients with sporadic GIST are reported to have an increased incidence of synchronous or metachronous secondary neoplasms at rates from around $4.5 \%$ to $43 \%$ [8-20].

The most frequent GIST-associated cancers are gastrointestinal cancers, lymphoma/leukemia, prostate cancer, breast cancer, and kidney cancer $[11,19]$. These tumors are discovered incidentally during the clinical management of GISTs or GISTs are discovered during the treatment or the follow up of other malignancies [11]. Data on prognostic factors and the impact of second tumors in GIST patients are very poor and just a few clinical trials reported that additional neoplasms had a significant impact on patient outcome [16-19].

The aim of this retrospective analysis was to assess the prevalence and the histotype of second tumors in a GIST series, to identify clinicopathologic characteristics of GISTs 
correlated to additional malignancies and to evaluate the impact of secondary neoplasms on GIST outcomes.

\section{Patients and methods}

This study was conducted at the Medical Oncology Unit 1 of IRCCS Ospedale Policlinico San Martino of Genoa (Italy). It was carried out in accordance with the Declaration of Helsinki, Good Clinical Practice and local ethical requirements.

Study population. We conducted a retrospective monocentric analysis of all consecutive patients with a histologically confirmed diagnosis of GIST followed and treated at our Medical Oncology Unit from April 2001 to October 2018. GIST diagnosis was performed with immunohistochemical staining using CD117, CD34, desmin, S100 protein, and smooth muscle actin. Since 2010 also molecular analysis of c-KIT (exon 9, 11, 13, and 17) and PDGFRa (exon 12, 14, and 18) genes using polymerase chain reaction (PCR) was performed.

GISTs before 2001 were excluded due to the high prevalence of misdiagnoses and miscoding in the 1990s [21]. Resected GISTs were classified by risk group of malignant behavior as very low, low, intermediate, and high according to Fletcher et al. [22] from 2002, Miettinen et al. from 2006 [23], Joensuu et al. from 2008 [24, 25].

We recorded all cases of additional tumors, including malignancies, benign tumors, and skin tumors that occurred before and after the diagnosis of GIST. The IARC-IACR recommendations for the definition of multiple primaries were used as criteria for inclusion or exclusion of tumors as second primary cancers [26]. Second tumors were defined as synchronous if diagnosed within 6 months of the diagnosis of GIST or metachronous if the diagnosis was made more than 6 months before or after the diagnosis of GIST [19]. Patients were followed from the date of diagnosis of GIST until death or loss of follow-up. The median follow-up was 5.5 years (range: $0.5-17$ years).

Clinical data of patients were collected from medical records: clinicopathological characteristics regarding patients (age, gender), GIST (primary site, size, mitotic rate, driven mutations, Joensuu risk classification) and second tumor (benign/malignant, histology, the timing of diagnosis) were assessed and are summarized in Table 1. Patients were divided into two main groups: patients with only a diagnosis of GIST and patients with the diagnosis of GIST and additional neoplasms.

Statistical analysis. Comparisons of the characteristics between the two groups of patients were performed using the $\chi^{2}$ test for categorical variables and Student's t-test for continuous variables.

In order to evaluate the relationship between clinical and biological characteristics of GIST and the occurrence of the second tumor(s), predictors of multiple cancer diagnoses were analyzed using univariate logistic regression. Clinico- pathological variables analyzed were age at GIST diagnosis ( \pm 65 years), sex, GIST stage (localized, locally advanced, metastatic), site (gastric vs other), size $( \pm 5 \mathrm{~cm})$, mitotic rate ( $<5$ vs $\geq 5 / 50 \mathrm{HPF}$ ), mutational status (c-KIT, PDGFRa, wild type), and Imatinib treatment.

Survival outcomes were evaluated using mOS and OS at 10 years (10y-OS). OS was measured from the diagnosis of GIST to death from any cause or last follow-up. Median OS was estimated with their $95 \%$ confidence interval. Survival curves of OS were generated using the Kaplan-Meier method [27]. Differences in OS were evaluated using the log-rank test (Mantel-Cox). In all the statistical analyses statistical significance was defined at the $p<0.05$ level. All statistical analyses were performed using SPSS V19.0 (SPSS Inc., USA).

Table 1. Patients' characteristics affected by GIST, alone or in association with second tumors.

\begin{tabular}{|c|c|c|c|}
\hline & $\begin{array}{c}\text { Total pts } \\
\mathrm{n}=145\end{array}$ & $\begin{array}{c}\text { GIST pts } \\
\text { only } \\
\mathrm{n}=114(79 \%)\end{array}$ & $\begin{array}{c}\text { GIST pts } \\
\text { with } 2^{\text {nd }} \\
\text { tumor(s) } \\
\text { n=31 (21\%) }\end{array}$ \\
\hline Patients characteristics & & $\mathrm{n}(\%)$ & \\
\hline $\begin{array}{l}\text { Median age at diagnosis, } \\
\text { years (range) }\end{array}$ & $61(15-84)$ & $60(15-84)$ & $66(38-80)$ \\
\hline $\begin{array}{l}\text { Sex } \\
\text { Male } \\
\text { Female }\end{array}$ & $\begin{array}{l}81(56) \\
64(44)\end{array}$ & $\begin{array}{l}65(57) \\
49(43)\end{array}$ & $\begin{array}{l}16(52) \\
15(48)\end{array}$ \\
\hline GIST disease characteristics & & $\mathrm{n}(\%)$ & \\
\hline $\begin{array}{l}\text { Primary site } \\
\text { Stomach } \\
\text { Small intestine } \\
\text { Rectum } \\
\text { Colon } \\
\text { Multiple site } \\
\text { Unknown }\end{array}$ & $\begin{array}{l}65(45) \\
53(36) \\
7(5) \\
2(1) \\
1(1) \\
17(12)\end{array}$ & $\begin{array}{l}53(47) \\
42(37) \\
6(5) \\
1(1) \\
0(0) \\
12(11)\end{array}$ & $\begin{array}{l}12(39) \\
11(36) \\
1(3) \\
1(3) \\
1(3) \\
5(16)\end{array}$ \\
\hline $\begin{array}{l}\text { Size } \\
\qquad \begin{array}{l}\text { Median, cm (range) } \\
\leq 2 \mathrm{~cm} \\
>2-5 \mathrm{~cm} \\
>5-10 \mathrm{~cm} \\
>10 \mathrm{~cm} \\
\text { Unknown }\end{array}\end{array}$ & $\begin{array}{l}6(1-28) \\
11(8) \\
40(28) \\
45(31) \\
17(12) \\
32(22)\end{array}$ & $\begin{array}{l}6(1-28) \\
9(8) \\
29(25) \\
36(32) \\
15(13) \\
25(22)\end{array}$ & $\begin{array}{c}5(1-25) \\
2(6) \\
11(36) \\
9(29) \\
2(6) \\
7(23)\end{array}$ \\
\hline $\begin{array}{l}\text { Mitotic rate } \\
\text { Median HPFs (range) } \\
\leq 5 / 50 \mathrm{HPFs} \\
>5 / 50 \mathrm{HPFs} \\
\text { Unknown }\end{array}$ & $\begin{array}{l}4(0-200) \\
61(42) \\
46(32) \\
38(26)\end{array}$ & $\begin{array}{l}4(0-200) \\
48(42) \\
33(29) \\
33(29)\end{array}$ & $\begin{array}{c}6(0-69) \\
13(42) \\
13(42) \\
5(16)\end{array}$ \\
\hline $\begin{array}{l}\text { Extent of disease at diagnosis } \\
\text { Localized } \\
\text { Locally advanced } \\
\text { Metastatic }\end{array}$ & $\begin{aligned} & 97(67) \\
& 7(5) \\
& 41(28)\end{aligned}$ & $\begin{array}{l}77(68) \\
6(5) \\
31(27)\end{array}$ & $\begin{array}{c}20(65) \\
1(3) \\
10(32)\end{array}$ \\
\hline $\begin{array}{l}\text { Treated with Imatinib } \\
\text { Yes } \\
\text { No }\end{array}$ & $\begin{array}{l}92(63) \\
53(37)\end{array}$ & $\begin{array}{l}78(68) \\
36(32)\end{array}$ & $\begin{array}{l}14(45) \\
17(55)\end{array}$ \\
\hline
\end{tabular}

Abbreviations: pts - patients, GIST - Gastrointestinal stromal tumors; HPFs - High-power fields; KIT - KIT proto-oncogene receptor tyrosine kinase; PDGFRa - platelet-derived growth factor receptor alpha 


\section{Results}

General GIST population. A total of 145 patients with a histological diagnosis of GIST were included in the analysis (Table 1).

Fifty-six percent of patients were males and the median age at diagnosis was 61 years (range 15-84). The most common primary site was stomach $(45 \%)$, followed by the small intestine (36\%) and rectum (5\%). In 17 patients (12\%), the GIST location was unknown. The median size was $6 \mathrm{~cm}$ (range 1-28) and the median mitotic rate was 4/50 HPFs. At diagnosis, 97 patients (67\%) were diagnosed with localized disease, 7 (5\%) had a locally advanced, and $41(28 \%)$ had metastatic disease.

Among patients with localized disease, 42 (43\%) belonged to the low or very low risk, $18(19 \%)$ to the intermediate category, and $37(38 \%)$ to the high-risk category (Table 2). Mutational analysis was performed in 95 patients (66\%) with the identification of 96 mutations because one patient had two synchronous GISTs with different c-KIT mutational status [28]. Seventy-three percent of patients had a mutation of the c-KIT gene, especially in exon 11 (58\%), 15\% of patients had a mutation of the PDGFRa gene, especially in exon 18 D842V (7\%), while $12 \%$ patients were wild type (Table 3 ).

Table 2. Risk category of GIST patients with and without second tumors.

\begin{tabular}{|c|c|c|c|c|}
\hline Risk category ${ }^{1}$ & $\begin{array}{c}\text { Total pts } \\
\mathbf{n}=\mathbf{9 7}\end{array}$ & $\begin{array}{c}\text { GIST pts only } \\
\quad \mathbf{n}=77\end{array}$ & $\begin{array}{c}\text { GIST pts with } \\
2^{\text {nd }} \text { tumors } \\
n=20\end{array}$ & p-value \\
\hline \multicolumn{5}{|c|}{$\mathrm{n}(\%)$} \\
\hline Low/Very low & $42(43)$ & $34(44)$ & $8(40)$ & \\
\hline Intermediate & $18(19)$ & $12(16)$ & $6(30)$ & 0.95 \\
\hline High & $37(38)$ & $31(40)$ & $6(30)$ & \\
\hline
\end{tabular}

Abbreviations: $\mathrm{n}$ - number of patients; pts - patients; GIST - Gastrointestinal stromal tumors; ${ }^{1}$ according to the risk categories proposed by Joensuu et al. [24]
Of the 145 patients diagnosed with a GIST, 31 patients (21\%) were diagnosed with at least one additional malignancy (Table 4).

Patients with GIST and second tumors. Among patients developing a second tumor, $13 \%$ of patients had a benign tumor and $87 \%$ a malignant disease. Twenty-five GIST patients $(84 \%)$ had a single additional cancer diagnosis, while $16 \%$ of patients had two or more additional cancer diagnoses. In 8 patients (21\%), the additional malignancy was synchronous while in 30 patients $(79 \%)$ was metachronous compared to the diagnosis of GIST. The most common second tumors associated with GIST were gastrointestinal tumors $(24 \%)$, hematological malignancies (18\%), genitourinary tumors (16\%), and skin cancers (13\%) (Table 4$)$.

Mutational analysis was performed in 25 patients (80\%), but one patient had two synchronous GISTs.

Eighty-five percent of GIST patients with the second tumor had the c-KIT mutation, $8 \%$ had PDGFRa mutations and $8 \%$ were wild-type. The patient with two synchronous GISTs carried two different mutations of c-KIT, one in exon 11 and the other one in exon 9. The median latent period between the diagnosis of GIST and the second metachronous tumor and vice-versa was 4 years (range 0.6-27.3 years, Table 5).

Predictors of an additional malignancy in GIST patients. Clinical and molecular factors were assessed to evaluate their association with the occurrence of an additional malignancy with GIST diagnosis. None of the factors assessed was found to be statistically significantly associated with the diagnosis of an additional malignancy in the unadjusted odds ratio (univariate analysis, Table 6). For this reason, an adjusted odds ratio (multivariate analysis) was not performed.

GIST with and without second tumor. Comparative analyses between GIST patients without second tumors and GIST patients with second tumor showed similar clinical, tumoral, and molecular characteristics, except for lower size

Table 3. Mutational status and risk category of GIST patients with and without second tumors.

\begin{tabular}{|c|c|c|c|}
\hline Mutational status & $\begin{array}{l}\text { Total mutations }=96^{*} \\
\quad(\text { total pts }=95)\end{array}$ & $\begin{array}{c}\text { Mutations of GIST } \\
\text { pts only }=70 \\
(\text { pts }=70)\end{array}$ & $\begin{array}{c}\text { Mutations of GIST } \\
\text { pts with } 2^{\text {nd }} \text { tumors }=26^{*} \\
(\mathrm{pts}=25)\end{array}$ \\
\hline & \multicolumn{3}{|c|}{$\mathrm{n}(\%)$} \\
\hline c-KIT mutation & $70(73)$ & $48(69)$ & $22(85)$ \\
\hline Exon 9 & $8(8)$ & $6(9)$ & $2(8)$ \\
\hline Exon 11 & $56(58)$ & $38(54)$ & $18(69)$ \\
\hline Exon 13 & $3(3)$ & $1(1)$ & $2(8)$ \\
\hline Exon 17 & $3(3)$ & $3(4)$ & 0 \\
\hline PDGFRa mutation & $14(15)$ & $12(17)$ & $2(8)$ \\
\hline Exon 12 & $2(2)$ & $2(3)$ & 0 \\
\hline Exon $18 \mathrm{D} 842 \mathrm{~V}$ & $7(7)$ & $6(9)$ & $1(4)$ \\
\hline Exon 18 D842Y & $1(1)$ & 0 & $1(4)$ \\
\hline Exon 18 not D842V & $4(4)$ & $4(6)$ & 0 \\
\hline Wild type & $12(12)$ & $10(14)$ & $2(8)$ \\
\hline
\end{tabular}

Abbreviations: pts - patients, GIST - Gastrointestinal stromal tumors; KIT - KIT proto-oncogene receptor tyrosine kinase; PDGFR - platelet-derived growth factor receptor alpha; ${ }^{\star}$ There are 26 mutations for 25 patients with second tumors because one patient had two synchronous GIST with two differ-

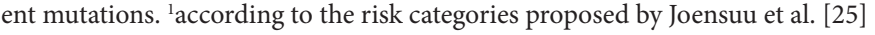


(>5 cm: $35 \%$ vs $45 \% ; \mathrm{p}=0.75)$, higher mitotic rate $(>5 / 50$ HPFs: $42 \%$ vs $29 \%$; $\mathrm{p}=0.24$; Table 1$)$, a higher presence of c-KIT mutation ( $85 \%$ vs $69 \%$ ) and a lower presence of PDGFRa mutation ( $8 \%$ vs $17 \%$ ) in GIST patients with second tumor $(\mathrm{p}=0.05)$ (Table 2).

The mOS was 9.6 years (range $0.6-17$ years; 95\% CI 6.6-12.5) and 15.5 years (range $0.1-17.1$ years; $95 \% \mathrm{CI}$ 9.1-21.8) in patients with and without secondary malignancies respectively ( $p=0.30$, Figure 1 ). In the group of patients with a second tumor, $54 \%$ died of GIST, $39 \%$ died of the second tumor, and 1 patient (7\%) died of non-cancer-related causes.

\section{Discussion}

The prevalence of the second primary tumors in cancer patients ranged from $6.6 \%$ to $9 \%$ and the risk of developing new primary cancer in cancer survivors is $10-20 \%$ higher compared to the general population [29-31]. Moreover, the incidence of second neoplasms is dependent on the prognosis of the first tumor, with second primary malignancies detected in less than $5 \%$ at 15 years in patients with unfavorable tumors and in about $15 \%$ at 25 years in patients with less unfavorable cancers [29].

GIST patients have an increased risk of developing second primary tumors, especially within the first year before and after the GIST diagnosis [20]. The incidence of additional malignancies in GIST patients ranged from $4.5 \%$ to $33 \%$ according to the different case series $[9,17]$.

This variety could be explained by different selection criteria of the studies regarding, particularly, the inclusion of benign neoplasms. The occurrence of second primary malignancies in GIST patients has been mainly described as case reports or case series and few retrospective analyses of large populations of patients are present in the literature, providing insufficient evidence on the association between these two entities.

Our study is one of the largest retrospective analyses on sporadic GISTs associated with second primary malignancies treated and followed at a single institute. The percentage of second tumors in our population $(21 \%)$ is in line with those reported in similar retrospective studies $[11,17,18,20$, 32]. Similarly to other studies, we observed that the gastrointestinal cancers are the most common second tumors in GIST patients and that the addition of a second tumor to GIST is associated with worse survival compared to GIST only patients [18-20].

Phan et al. [33] were the first to compare the incidence of second primary malignancies after GIST diagnosis in pre-Imatinib (1992-2001) and in the Imatinib era (20022009). They found that the rate of the second primary tumors after GIST diagnosis in the Imatinib era was $7.07 \%$ compared with $1.15 \%$ in the pre-Imatinib era $(\mathrm{p}=0.03)$. This difference was mainly accounted for a higher incidence of colon and renal cancer, while the rate of melanoma was
Table 4. Second tumors' characteristics.

\begin{tabular}{lc}
\hline \multicolumn{2}{c}{ Second tumors $\mathbf{n}=\mathbf{3 8}$} \\
\hline Characteristics & $\mathbf{n}(\mathbf{\%})$ \\
\hline Type & $\mathbf{2 9}(\mathbf{7 6})$ \\
Malignant & $\mathbf{9 ( 2 4 )}$ \\
Benign & \\
Histological type & $9(24)$ \\
Gastrointestinal tumors & $7(18)$ \\
Hematological tumors & $6(16)$ \\
Genitourinary tumors & $5(13)$ \\
Skin tumors & $3(8)$ \\
Lung tumors & \\
Others & $2(5)$ \\
Thyroid tumors & $3(8)$ \\
Mesenchymal tumors & $1(3)$ \\
Pituitary tumors & $1(3)$ \\
Breast cancer & $1(3)$ \\
Head and neck & \\
Timing of diagnosis & $8(21)$ \\
Synchronous & $16(42)$ \\
Metachronous & $14(37)$ \\
Prior to GIST diagnosis & \\
After GIST diagnosis &
\end{tabular}

Abbreviations: GIST - gastrointestinal stromal tumors

significantly lower in the Imatinib era compared with the pre-Imatinib era $(\mathrm{p}=0.03)$.

The main cause of the increased incidence of second tumors in the Imatinib era is the increased survival of metastatic GIST patients and, therefore, more time available to develop second tumors.

In fact, in the pre-Imatinib era, metastatic GIST patients had a median survival of 10-20 months [34], but with the introduction of Imatinib in clinical practice the median survival has subsequently increased to about 5 years, with further survival improvements over time according to molecular subtypes [35]. The revolutionary survival increase of GIST patients is a key example of how the advancement in screening, diagnosis, treatment and follow up have increased the life expectancy of cancer patients and, consequently, how cancer survivors live long enough to develop second primary tumors. Rodriquenz et al. [8] indeed suggested that GIST could be considered as a "sentinel tumor". Our study underlined, therefore, how the surveillance of second malignancies should be an important component of the clinical management and follow-up of GIST patients, especially in the first years after GIST diagnosis. This is important to highlight because, even today, many symptoms and new lesions in GIST patients are still misinterpreted. New radiological atypical masses in patients with a history of GIST should be biopsied to distinguish between GIST relapse and a second primary tumor. For example, GISTs rarely metastasize to lymph nodes, but GIST patients have a higher risk of developing lymphomas, so new lymphadenopathies should warrant consideration for additional work-up. Similarly, new symptoms, especially 
Table 5. Patients with GIST associated with other primary malignant and benign neoplasms.

\begin{tabular}{|c|c|c|c|c|c|c|c|}
\hline Pts n. & $1^{\text {st }}$ tumor (age) & $2^{\text {nd }}$ tumor (age) & $3^{\text {rd }}$ tumor (age) & $4^{\text {th }}$ tumor (age) & $\begin{array}{c}\text { Time GIST } \\
\text { to } 2^{\text {nd }} \text { tumor } \\
\text { (years) }\end{array}$ & $\begin{array}{c}\text { Time GIST } \\
\text { to } 3^{\text {rd }} \text { tumor } \\
\text { (years) }\end{array}$ & $\begin{array}{c}\text { Time GIST } \\
\text { to } 4^{\text {th }} \text { tumor } \\
\text { (years) }\end{array}$ \\
\hline 1 & Gastric GIST (44) & Duodenal Adk (48) & - & - & 5.2 & - & - \\
\hline 2 & GIST (78) & CRC (86) & - & - & 7.6 & - & - \\
\hline 3 & Epithelioma (78) & GIST (80) & Skin SCC (90) & - & 3.3 & 10.3 & - \\
\hline 4 & GIST (62) & Skin SCC (73) & - & - & 11.5 & - & - \\
\hline 5 & Lung Adk (59) & Mixoma (59) & Colon Adenoma (64) & Duodenal GIST (65) & 6.7 & 6.7 & 1.3 \\
\hline 6 & Gastric GIST (57) & CRC (60) & - & - & 3.9 & - & - \\
\hline 7 & Ileal GIST (55) & Seminoma (56) & - & - & 0.8 & - & - \\
\hline 8 & NHL (58) & Gastric GIST (59) & - & - & 0.8 & - & - \\
\hline 9 & Duodenal GIST (58) & Lung Carcinoid (59) & - & - & 0.2 & - & - \\
\hline 10 & Gastric GIST (61) & $\operatorname{CLL}(62)$ & - & - & 1.3 & - & - \\
\hline 11 & Gastric GIST (77) & Prostate Cancer (82) & - & - & 4.7 & - & - \\
\hline 12 & MGUS (14) & Gastric GIST (42) & - & - & 27.3 & - & - \\
\hline 13 & Gastric GIST (56) & CRC (62) & - & - & 5.9 & - & - \\
\hline 14 & Gastric GIST (78) & $\mathrm{CRC}(78)$ & - & - & 0.3 & - & - \\
\hline 15 & NHL (37) & Jejunal GIST (39) & - & - & 0.8 & - & - \\
\hline 16 & CRC (66) & Prostate Cancer (71) & GIST (77) & - & 5.3 & 10.3 & - \\
\hline 17 & GIST (74) & Thyroid Cancer (76) & - & - & 2.4 & - & - \\
\hline 18 & Ileal GIST (74) & Pelvic Melanoma (74) & - & - & 0.2 & - & - \\
\hline 19 & Epithelioma (54) & Ileal GIST (61) & - & - & 7.1 & - & - \\
\hline 20 & Pituitary Adenoma (68) & Gastric GIST (72) & - & - & 4.5 & - & - \\
\hline 21 & Prostate Cancer (64) & Gastric GIST (64) & Jejunal GIST (64) & Lung Adk (66) & 0.6 & 0 & 2.2 \\
\hline 22 & Gastric GIST (48) & Renal Cancer (52) & - & - & 4.3 & - & - \\
\hline 23 & Rectal GIST (58) & Prostate cancer (58) & - & - & 0 & - & - \\
\hline 24 & Breast Cancer (63) & Jejunal GIST (66) & - & - & 3.5 & - & - \\
\hline 25 & Ileal GIST (68) & MGUS (69) & - & - & 0.6 & - & - \\
\hline 26 & Gastric GIST (78) & Renal Cancer (78) & Ewing's Sarcoma (81) & - & 0 & 2.8 & - \\
\hline 27 & Basal Cell Carcinoma (73) & CRC (75) & Ileal GIST (78) & CRC (78) & 3.1 & 1.3 & 0 \\
\hline 28 & Jejunal GIST (63) & Thyroid Cancer (64) & - & - & 1.1 & - & - \\
\hline 29 & Jejunal GIST (68) & H\&N Cancer (68) & - & - & 0.3 & - & - \\
\hline 30 & AML (56) & Colon GIST (72) & - & - & 16 & - & - \\
\hline 31 & NHL (52) & Gastric GIST (58) & - & - & 5.3 & - & - \\
\hline
\end{tabular}

Abbreviations: GIST - Gastrointestinal stromal tumors; SCC - squamous cell carcinoma; Adk - adenocarcinoma; AML - Acute Myeloid Leukemia; CLL - Chronic Lymphocytic Leukemia; CRC - colorectal cancer; MGUS - monoclonal gammopathy of undetermined significance; NHL - non-Hodgkin lymphoma, H\&N - head and neck cancer; "GIST": metastatic GIST without a specific site of origin; "0": diagnosis in the same surgical intervention. Time to GIST and $2^{\text {nd }} / 3^{\text {rd } /} 4^{\text {th }}$ tumor $\leq 0.5$ : synchronous tumors

gastrointestinal ones, should require further diagnostic assessment.

There is still no consensus on guidelines regarding the surveillance, oncologic care, and further management of cancer survivors. In this scenario, targeted screening in association with long-term and intensive surveillance strategies are needed in GIST patients. These strategies in the context of survivorship care could be of particular benefit in GIST patients as an important tool for early diagnosis of second cancers, more than other types of tumors.

The pathophysiological and genetic mechanisms of the high risk of GIST for developing secondary malignancies are still unknown. In our analysis, we found that GIST patients with the second tumor had lower size, higher mitotic rate, higher presence of c-KIT mutation, especially the exon 11 mutation, and a lower presence of PDGFR $\alpha$ mutation compared to GIST only patients. These correlations were not statistically significant but similar to the results of other retrospective analyses [19, 32]. In our study, none of the clinical and molecular factors assessed was found to be statistically significantly associated with the diagnosis of an additional malignancy, due to the relatively small number of patients and the lack of some data, similar to other retrospective analyses [36]. This is the major limitation of our study related to the retrospective nature of the analysis with the lack of all complete data limiting, therefore, all statistical analysis.

Further analyses on larger populations and cancer registries are needed to better analyze the epidemiological corre- 
Table 6. Univariate analysis of predictors of additional malignancies in GIST patients.

\begin{tabular}{|c|c|c|}
\hline \multicolumn{3}{|c|}{ Unadjusted Odds Ratio } \\
\hline Characteristic & OR (95\% CI) & p-value \\
\hline Age ( \pm 65 years $)$ & $0.81(0.29-2.46)$ & 0.7 \\
\hline $\begin{array}{l}\text { Sex } \\
\text { Male } \\
\text { Female }\end{array}$ & $0.83(0.29-2.39)$ & 0.7 \\
\hline $\begin{array}{l}\text { Primary site } \\
\text { Esophagogastric } \\
\text { Other }\end{array}$ & $1.16(0.37-3.69)$ & 0.8 \\
\hline $\begin{array}{l}\text { Stage } \\
\text { Localized } \\
\text { Locally advanced } \\
\text { Metastatic }\end{array}$ & $\begin{array}{l}0.75(0.07-8.43) \\
0.87(0.09-8.16)\end{array}$ & $\begin{array}{l}0.8 \\
0.9\end{array}$ \\
\hline $\begin{array}{l}\mathrm{T} \mathrm{cm} \\
\qquad 5 \mathrm{~cm} \\
\quad \geq 5 \mathrm{~cm}\end{array}$ & $0.55(0.16-1.83)$ & 0.3 \\
\hline $\begin{array}{l}n \text { mitosis } \\
\quad<5 / 50 \mathrm{HPF} \\
\quad \geq 5 / 50 \mathrm{HPF}\end{array}$ & $1.39(0.15-13.24)$ & 0.8 \\
\hline $\begin{array}{l}\text { Risk classification }{ }^{1} \\
\text { Low/Very low } \\
\text { Intermediate } \\
\text { High }\end{array}$ & $\begin{array}{l}1.38(0.24-8.13) \\
0.67(0.06-7.13)\end{array}$ & $\begin{array}{l}0.7 \\
0.7\end{array}$ \\
\hline $\begin{array}{l}\text { Mutation } \\
\text { c-KIT } \\
\text { PDGFRa } \\
\text { Wild Type }\end{array}$ & $\begin{array}{l}2.52(0.74-8.59) \\
0.25(0.03-2.43)\end{array}$ & $\begin{array}{l}0.1 \\
0.2\end{array}$ \\
\hline $\begin{array}{l}\text { Imatinib treatment } \\
\text { Yes } \\
\text { No }\end{array}$ & $1.40(0.30-6.43)$ & 0.7 \\
\hline
\end{tabular}

Abbreviations: GIST - Gastrointestinal stromal tumors; HPFs - highpower fields; c-KIT - KIT proto-oncogene receptor tyrosine kinase; PDGFR $\alpha$ - platelet-derived growth factor receptor alpha; OR - odds ratio; CI - confidence interval; ${ }^{1}$ according to the risk categories proposed by Joensuu et al. [25]

lation of GIST patients and second tumors. In addition, more comprehensive follow-up programs should be addressed for closer surveillance of GIST survivors especially during the first 5 years after diagnosis but preferably to consider up to 10 years.

Moreover, further molecular analyses are required to investigate the possible biological association between GIST and other malignancies, identifying which GIST patients are genetically more susceptible to the development of second cancers.

The identification of gene expression signature reflecting the biological characteristics with prognostic and predictive value is needed also for GIST patients, like other types of tumors, to better define prognostic patient subsets and to identify appropriate surveillance and clinical management [37-41].

In conclusion, this retrospective analysis of a GIST population showed a second malignancies' incidence of around $20 \%$. GIST patients have an increased risk of developing second primary malignancies and GIST is often diagnosed incidentally after another primary tumor. It is not clear if

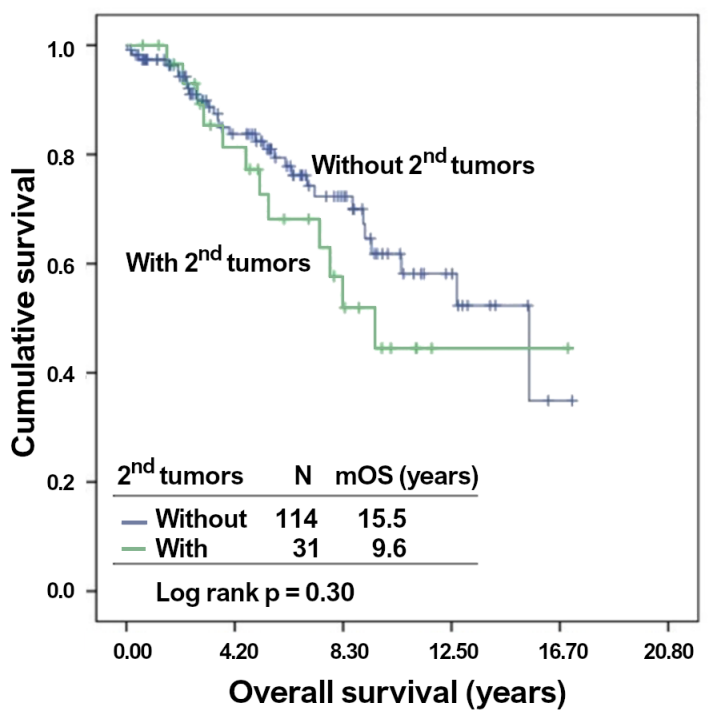

Figure 1. Kaplan-Meier survival curves of GIST patients with and without second malignancies.

there is an association between GISTs and the occurrence of other tumors. Further analyses are needed to investigate the association between GIST and second tumors. Moreover, new follow-up protocols should be routinely addressed for GIST patients in order to promptly identify the development of second malignancies.

Acknowledgments: This research did not receive any specific grant from funding agencies in the public, commercial, or not-for-profit sectors.

\section{References}

[1] SØREIDE K, SANDVIK OM, SØREIDE JA, GILJACA V, JURECKOVA A et al. Global epidemiology of gastrointestinal stromal tumours (GIST): a systematic review of population-based cohort studies. Cancer Epidemiol 2016; 40: 39-46. https://doi.org/10.1016/j.canep.2015.10.031

[2] CHIANG NJ, CHEN LT, TSAI CR, CHANG JS. The epidemiology of gastrointestinal stromal tumors in Taiwan, 19982008: a nation-wide cancer registry-based study. BMC Cancer 2014; 14: 102. https://doi.org/10.1186/1471-2407-14-102

[3] MA GL, MURPHY JD, MARTINEZ ME, SICKLICK JK. Epidemiology of gastrointestinal stromal tumors in the era of histology codes: results of a population-based study. Cancer Epidemiol Biomarkers Prev 2015; 24: 298-302. https://doi. org/10.1158/1055-9965.EPI-14-1002

[4] CORLESS CL, BARNETT CM, HEINRICH MC. Gastrointestinal stromal tumours: origin and molecular oncology. Nat Rev Cancer 2011; 11: 865-878. https://doi.org/10.1038/ nrc3143

[5] AGARAM NP, BESMER P, WONG GC, SOCCI ND, MAKI RG et al. Pathologic and molecular heterogeneity in imatinib-stable or imatinib-responsive gastrointestinal stromal tumors. Clin Cancer Res 2007; 13: 170-181. https://doi. org/10.1158/1078-0432.CCR-06-1508 
[6] DEMATTEO RP, BALLMAN KV, ANTONESCU CR, GUO T, SOCCI ND et al. Adjuvant imatinib mesylate after resection of localised, primary gastrointestinal stromal tumour: a randomised, double-blind, placebo-controlled trial. Lancet 2009; 373: 1097-1104. https://doi.org/10.1016/S01406736(09)60500-6

[7] BURGOYNE AM, SOMAIAH N, SICKLICK JK. Gastrointestinal stromal tumors in the setting of multiple tumor syndromes. Curr Opin Oncol 2014; 26: 408-414. https://doi. org/10.1097/CCO.0000000000000089

[8] RODRIQUENZ MG, ROSSI S, RICCI R, LAROCCA M, DIPASQUALE A et al. Gastrointestinal stromal tumors (GISTs) and second malignancies. A novel "sentinel tumor"? A monoinstitutional, STROBE-compliant observational analysis. Medicine (Baltimore) 2016; 95: e4718. https://doi. org/10.1097/MD.0000000000004718

[9] AGAIMY A, WÜNSCH PH, SOBIN LH, LASOTA J, MIETTINEN M. Occurrence of other malignancies in patients with gastrointestinal stromal tumors. Semin Diagn Pathol 2006; 23: 120-129. https://doi.org/10.1053/j.semdp.2006.09.004

[10] LISZKA Ł, ZIELIŃSKA-PAJAK E, PAJAK J, GOŁKA D, HUSZNO J. Coexistence of gastrointestinal stromal tumors with other neoplasms. J Gastroenterol 2007; 42: 641-649. https://doi.org/10.1007/s00535-007-2082-4

[11] MURPHY JD, MA GL, BAUMGARTNER JM, MADLENSKY L, BURGOYNE AM et al. Increased risk of additional cancers among patients with gastrointestinal stromal tumors: a population-based study. Cancer 2015; 121: 2960-2967. https://doi.org/10.1002/cncr.29434

[12] FERREIRA SS, WERUTSKY G, TONETO MG, ALVES JM, PIANTÁ CD et al. Synchronous gastrointestinal stromal tumors (GIST) and other primary cancers: case series of a single institution experience. Int J Surg 2010; 8: 314-317. https://doi.org/10.1016/j.ijsu.2010.03.008

[13] GONCALVES R, LINHARES E, ALBAGLI R, VALADÃO $\mathrm{M}$, VILHENA B et al. Occurrence of other tumors in patients with GIST. Surg Oncol 2010; 19: e140-143. https://doi. org/10.1016/j.suronc.2010.06.004

[14] PONTI G, LUPPI G, MARTORANA D, ROSSI G, LOSI L et al. Gastrointestinal stromal tumor and other primary metachronous or synchronous neoplasms as a suspicion criterion for syndromic setting. Oncol Rep 2010; 23: 437-444.

[15] SEVINC A, SEKER M, BILICI A, OZDEMIR NY, YILDIZ $\mathrm{R}$ et al. Co-existence of gastrointestinal stromal tumors with other primary neoplasms. Hepatogastroenterology 2011; 58: 824-830.

[16] VASSOS N, AGAIMY A, HOHENBERGER W, CRONER RS. Coexistence of gastrointestinal stromal tumors (GIST) and malignant neoplasms of different origin: prognostic implications. Int J Surg 2014; 12: 371-377. https://doi. org/10.1016/j.ijsu.2014.03.004

[17] PANDURENGAN RK, DUMONT AG, ARAUJO DM, LUDWIG JA, RAVI V et al. Survival of patients with multiple primary malignancies: a study of 783 patients with gastrointestinal stromal tumor. Ann Oncol 2010; 21:2107-2111. https://doi.org/10.1093/annonc/mdq078
[18] KRAMER K, WOLF S, MAYER B, SCHMIDT SA, AGAIMY A et al. Frequence, Spectrum and Prognostic Impact of Additional Malignancies in Patients With Gastrointestinal Stromal Tumors. Neoplasia 2015; 17: 134-140. https://doi. org/10.1016/j.neo.2014.12.001

[19] SMITH MJ, SMITH HG, MAHAR AL, LAW C, KO YJ. The impact of additional malignancies in patients diagnosed with gastrointestinal stromal tumors. Int J Cancer 2016; 139: 1744-1751. https://doi.org/10.1002/ijc.30231

[20] LAI BR, WU YT, KUO YC, HSU HC, CHEN JS et al. Targeted ultra-deep sequencing unveils a lack of driver-gene mutations linking non-hereditary gastrointestinal stromal tumors and highly prevalent second primary malignancies: random or nonrandom, that is the question. Oncotarget 2016; 7: 83270-83277. https://doi.org/10.18632/oncotarget.12452

[21] PEREZ EA, LIVINGSTONE AS, FRANCESCHI D, ROCHA-LIMA C, LEE DJ et al. Current incidence and outcomes of gastrointestinal mesenchymal tumors including gastrointestinal stromal tumors. J Am Coll Surg 2006; 202: 623-629. https://doi.org/10.1016/j.jamcollsurg.2006.01.002

[22] FLETCHER CDM, BERMAN JJ, CORLESS C, GORSTEIN F, LASOTA J et al. Diagnosis of gastrointestinal stromal tumors: a consensus approach. Hum Pathol 2002; 33: 459-465. https://doi.org/10.1053/hupa.2002.123545

[23] MIETTINEN M, LASOTA J. Gastrointestinal stromal tumors: pathology and prognosis at different sites. Semin Diagn Pathol 2006; 23: 70-83. Semin Diagn Pathol 2006; 23: 70-83. https://doi.org/10.1053/j.semdp.2006.09.001

[24] JOENSUU H. Risk stratification of patients diagnosed with gastrointestinal stromal tumor. Hum Pathol 2008; 39: 14111419. https://doi.org/10.1016/j.humpath.2008.06.025

[25] JOENSUU H, VEHTARI A, RIIHIMÄK J, NISHIDA T, STEIGEN SE et al. Risk of recurrence of gastrointestinal stromal tumour after surgery: an analysis of pooled population-based cohorts. Lancet Oncol 2012; 13: 265-274. https:// doi.org/10.1016/S1470-2045(11)70299-6

[26] WORKING GROUP REPORT. International Rules for Multiple Primary Cancers (ICD-0 Third Edition). Eur J Cancer Prev 2005; 14: 307-308. https://doi.org/10.1097/00008469200508000-00002.

[27] KAPLAN E, MEIER P. Nonparametric estimation from incomplete observations. J Am Stat Assoc 1958; 53: 457-481. http://www.jstor.org/stable/2281868

[28] COMANDINI D, DAMIANI A, PASTORINO A. Synchronous GISTs associated with multiple sporadic tumors: a case report. Drugs Context 2017; 6: 212307. https://doi. org/10.7573/dic. 212307

[29] GRUNDMANN RT, MEYER F. Second Primary Malignancy among Cancer Survivors - Epidemiology, Prognosis and Clinical Relevance. Zentralbl Chir 2012; 137: 565-574. https://doi.org/10.1055/s-0031-1283939

[30] FAST STATS: AN INTERACTIVE TOOL FOR ACCESS TO SEER CANCER STATISTICS. Surveillance Research Program, National Cancer Institute. (Accessed on 9-242019) https://seer.cancer.gov/faststats

[31] AIRTUM WORKING GROUP. Italian cancer figures, report 2013: multiple tumours. Epidemiol Prev 2013; 37: 1-152. 
[32] HECHTMAN JF, DEMATTEO R, NAFA K, CHI P, ARCILA ME et al. Additional Primary Malignancies in Patients with Gastrointestinal Stromal Tumor (GIST): A Clinicopathologic Study of 260 Patients with Molecular Analysis and Review of the Literature. Ann Surg Oncol 2015; 22: 2633-2639. https://doi.org/10.1245/s10434-014-4332-Z

[33] PHAN K, MARTIRES K, KURLANDER DE, GADDIPATI $\mathrm{K}$, XAVIER $\mathrm{M}$ et al. The incidence of second primary malignancies after gastrointestinal stromal tumor before and after the introduction of imatinib mesylate. Transl Cancer Res 2014; 3: 152-159. https://doi.org/10.3978/j.issn.2218676X.2013.07.04

[34] GOLD JS, VAN DER ZWAN SM, GÖNEN M, MAKI RG, SINGER $S$ et al. Outcome of metastatic GIST in the era before tyrosine kinase inhibitors. Ann Surg Oncol 2007; 14: 134-142. https://doi.org/10.1245/s10434-006-9177-7

[35] CASALI PG, ZALCBERG J, LE CESNE A, REICHARDT $\mathrm{P}, \mathrm{BLAY} J Y$ et al. Ten-year progression-free and overall survival in patients with unresectable or metastatic GI stromal tumors: long-term analysis of the European Organisation for Research and Treatment of Cancer, Italian Sarcoma Group, and Australasian Gastrointestinal Trials Group intergroup phase III randomized trial on imatinib at two dose levels. J Clin Oncol 2017; 35: 1713-1720. https://doi.org/10.1200/ JCO.2016.71.0228
[36] RUBIÓ-CASADEVALL J, BORRÀS JL, CARMONA-GARCÍA MC, AMEIJIDE A, GONZALEZ-VIDAL A et al. Correlation between mutational status and survival and second cancer risk assessment in patients with gastrointestinal stromal tumors: a population-based study. World J Surg Oncol 2015; 13: 47. https://doi.org/10.1186/s12957-015-0474-0

[37] MATONDO A, JO YH, SHAHID M, CHOI TG, NGUYEN $\mathrm{MN}$ et al. The Prognostic 97 Chemoresponse Gene Signature in Ovarian Cancer. Sci Rep 2017; 7: 9689. https://doi. org/10.1038/s41598-017-08766-5

[38] SHAHID M, CHOI TG, NGUYEN MN, MATONDO A, JO YH et al. An 8-gene signature for prediction of prognosis and chemoresponse in non-small cell lung cancer. Oncotarget 2016; 7: 86561-86572. https://doi.org/10.18632/oncotarget. 13357

[39] SHAHID M, CHO KM, NGUYEN MN, CHOI TG, JO YH et al. Prognostic value and their clinical implication of 89gene signature in glioma. Oncotarget 2016; 7: 51237-51250. https://doi.org/10.18632/oncotarget.9983

[40] NGUYEN MN, CHOI TG, NGUYEN DT, KIM JH, JO YH et al. CRC-113 gene expression signature for predicting prognosis in patients with colorectal cancer. Oncotarget 2015; 6: 31674-31692. https://doi.org/10.18632/oncotarget.5183

[41] AKTER S, CHOI TG, NGUYEN MN, MATONDO A, $\mathrm{KIM} \mathrm{JH}$ et al. Prognostic value of a 92-probe signature in breast cancer. Oncotarget 2015; 6: 15662-15680. https://doi. org/10.18632/oncotarget.3525 